\title{
The Effect of Leadership Properties Against Effectiveness of Leadership of School Heads (Case Study on Head of State 3st Vocational School, White Portrait, Riau)
}

\author{
Zulfikar $^{1}$, Eka Daryanto ${ }^{2}$ \\ \{Zulfikar.pgri@live.com \} \\ Universitas Negeri Medan, Indonesia ${ }^{1,2}$
}

\begin{abstract}
School is an organization that requires good management, organizational school has an organizational structure, the school administration has input-processoutput elements. At the most operational level, the principal is the person at the forefront who coordinates efforts to improve quality learning. In practice in RokanHilir District, the principal is a qualified senior teacher who holds the post. Nothing is not a teacher in the adoption of a principal. So, a teacher can expect that if "lucky" one day his career will lead to the position as headmaster. The principal should be a privileged position. For one thing, the headmaster's position is not just a managerial position with all sorts of titles. Indeed, in the sense that the head of a work unit, in fact the principal's position is no different from other managerial positions. At least the function is the same, that is maximize the utilization of available resources productively to achieve the goals set for the work unit. To some extent, the principal as head of a work unit, plays the same role as the manager for other work. Management in the broad sense is: A process of achieving goals through efficient utilization of human and material resources, Leading is one of the four management functions. The theory of nature seeks to determine the list of different traits to determine leadership effectiveness. Thus the theory of leadership of nature, and the identification of six noble leadership traits of Ghiselli.leadership theory of nature assumes that different traits determine leadership effectiveness. The characteristics of effective leadership are the ability of supervision, the need for job attainment, intelligence, assertiveness, self-assurance and initiative. In traits theory states the effectiveness of leadership depends on the character of the leader. The qualities they possess include personality, physical superiority, and social ability. A leader must have astabrata, which are eight superior attributes associated with nature such as earth, fire, wind, space, moon, sun, stars. In this regard, the study reveals the influence of leadership of the Principal's character on its leadership effectiveness. The results of the study measured that there is a positive correlation between the leadership nature and effectiveness of the leadership of SMKN 3 Tanah Putih, RokanHilir Regency, with a big influence over a third.
\end{abstract}

Keywords: Leadership Nature, Effectiveness, Principal

\section{Introduction}

Schools as an institution or institution of education is a means of carrying out service $\mathrm{s}$ and processes of school education is not only made as a gathering place between teachers and students, but a system that is very complex and dynamic (Sagala, 2013: 70) School is an organization that requires management good, organizationally the school has an organizational structure, school administration has an 
input-process-output element. At the most operational level, the principal is a person at the forefront who coordinates efforts to improve quality learning. In practice in Riau Province, the principal is a senior teacher who has the qualifications to occupy that position. No one who is not a teacher is appointed as the principal. So, a teacher can hope that if "lucky" one day his career will lead to the position of principal. Good leaders are told and communicate clear personal and educational values that represent their moral goals for school' (p. 53).Vision is increasingly considered an important component of effective leadership. Beare et al. (1992) suggested the work of Bennis and Nanus (1985) to articulate ten emerging generalizations about leadership, four of which relate directly to vision:

1. Prominent leaders have a vision for their organization.

2. Vision must be communicated in a way that guarantees commitment among members of the organization.

3. Vision communication requires meaning communication.

4. Attention must be given to institutionalizing a vision if leadership becomes successful.

This generalization is basically a normative view of the centrality of vision for effective leadership. There is a high level of support for the idea of visionary leadership, but Foreman (1998 )'s concept review shows that it remains very problematic. Kouzes and Posner (1996: 24) say that 'inspiring a shared vision is a leadership practice that [its head] is most uncomfortable', while Fullan (1992: 83) adds that 'visual building is a highly sophisticated dynamic process that few organizations can survive

Linking models with leadership development Leadership can be understood as a process of influence based on clear values and beliefs and leads to 'vision' for school. The vision is articulated by leaders who strive to gain staff and stakeholder commitment to a better future for the school, students and stakeholders. Each of the leadership models discussed in this book is partial. They provide a different but not unique perspective on school leadership. Sergiovanni (1984: 6) adds that 'leadership theory and practice provide limited views, staying excessively on some aspects of leadership towards the virtual exclusion of others'.

The increasing demands on school leaders come from two contrasting sources. First, the accountability pressure faced by perpetrators is very large and continues to grow, in many countries. The government, parents and the wider community expect a lot from their schools and most of these expectations are transmitted through the principal. Crow (2006: 310), referring to the United States, refers to the increasing demands of society in a policy environment with increasingly high bets.

Leader effectiveness is sometimes measured on the basis of the leader's contribution to the quality of group processes perceived by followers or observers from outside. Is the leader able to increase the cohesiveness of members of the member cooperation groups, motivate members, solve problems, make decisions and reconcile conflicts between members? It is very difficult to evaluate effective leaders because there are many alternative measures of effectiveness, and it is not clear which size is most relevant. Some researchers try to combine several measures into one composite criterion, but this approach requires subjective judgment in giving the weight of the assessment to each measure. Lussier (2009: 316) gives the meaning of leadership is the process of influencing employees to work towards achieving organizational goals. The same thing VethzalRivai (2003: 2) defines leadership is an influential process in determining organizational goals, motivating followers behaviorto achieve goals, influence to improve the group and culture.

The leadership meant here is the leadership of the principal. Researchers want to examine and analyze the nature of leadership variables, in this case VethzalRivai (2003: 11) asserts that nature theory tries to identify typical characteristics (physical, mental, personality) that are associated with leadership success. Furthermore VethzalRivai emphasized that the nature of the theory emphasizes the personal attributes of leaders. Lussier (2009: 317) says the nature of leadership seeks to determine different characteristics in producing leadership effectiveness.

Furthermore Lussier (2009) raised the study conducted by Ghiselli (1971) from 300 managers studied resulting that certain traits are important for effective leadership.

For some of the tioris and rationality studies above, the researcher wants to further assess the effectiveness of the school principal with the title "The Effect of Leadership on the Effectiveness of Leadership in the Head of State Vocational High School 3 Tanah PutihKab. RokanHilir, Riau ". 


\section{Research Methods}

1. This research was conducted at SMK Negeri 3 Tanah Putih, RokanHilir Regency, Riau, which was the object of the study were all teachers of Tanah Putih Vocational High School 3 in RokanHilir Regency, Riau. The method used is survey method. The population in the study were all teachers of SMK Negeri 3 Tanah Putih, RokanHilir Regency, Riau, amounting to 32 people, while the determination of the sample was determined by the researcher with consideration (purposive) namely, representing each department, with the weight of the number of vocational teachers in each department, so that the sample was 32 all teachers in Tanah Putih 3 Vocational School, RokanHilir Regency, Riau.

2. The measurement of the leadership nature of the head of SMK Negeri 3 Tanah Putih in RokanHilir Regency, Riau was taken quoted from Lussier (2009) including: (1) supervision ability, (2) the need for job achievement, (3) intelligence, (4) belief, (5) confidence, and (6) initiative. Furthermore, the measurement of leadership effectiveness variables includes: (1) the right perception, (2) maturity level, (3) the right assessment of the task, (4) background and experience, (5) leader's expectations and style, (6) professional relationship .

3. Nature leadership variables have 25 statement items, where very effective statements are given a weight of 4 , effectively given a weight of 3 , less effective are given a weight of 2 , and an ineffective statement is given a weight of 1 . Furthermore, the principal's leadership effectiveness variable has 30 items. statement, where the statement is very appropriate / always given a weight of 4, accordingly / often given a weight of 3 , less appropriate / rarely given a weight of 2 , and the statement is not appropriate / never given a weight of 1 .

4. The research instrument was in the form of a questionnaire, which was compiled from the theory concept proposed by Lussier (2009), a questionnaire form was adopted from the Likert-4 scale, before the questionnaire was prepared the researcher had made a list of variable matrices along with variable indicators to produce statement items as instruments. research. Data analysis method, using correlation and regression analysis. For calculation purposes, the research data is processed with Microsoft Excel software, and SPSS software (Statistical Product and service Solution).

5. To analyze the influence of nature (X) leadership variables on the effectiveness of the leadership (Y) of the head of Tanah Putih Vocational High School 3 SMK Hilir, Riau, the formulation or step of the analysis is carried out in two stages, each first step (1) determining whether there is a correlation between variables (r), and the second stage (2) a measure of its influence with regression analysis.

\section{Research Result}

Overview of Leadership The nature of the Principal The results of data processing are the leadership characteristics of the Principal of the Vocational School, which can be seen in table 1. the results of calculations that show that the percentage of each weight asked by the respondent.

Table 1.Score Based on Respondents' Responses on Leadership Nature of Principal Vocational High School 3 Tanah Putih, RokanHilir Regency, Riau

\begin{tabular}{|c|l|c|c|}
\hline Amount & \multicolumn{1}{|c|}{ Category } & Total & \% \\
\hline 1 & Ineffective & 11 & 1,4 \\
\hline 2 & Less effective & 51 & 6,6 \\
\hline 3 & Effective & 329 & 41 \\
\hline 4 & Very effective & 409 & 51 \\
\hline
\end{tabular}

From the data above, there are 51 percent stated to be very effective, 41 percent effective, the remaining around 8 percent stated less (less effective / ineffective).If the results of the calculation of this variable are extended further to find out the level of leadership traits, then with the highest ideal score $=4 \times 25$ items $\times 32$ respondents $=3200$ while the total score of the respondents' assessment results is 2736 , so the ratio is = $(2736 / 3200) \times 100 \%=85.50 \%$ which describes that the leadership level of the principal has $85.5 \%$ of ideal conditions. 
Overview of the Effectiveness of Principal Leadership Results of data processing variables Effectiveness of leadership of the Head of the Negeri 3 Tanah Putih Vocational High School (SMK) RokanHilir Regency, Riau, which is based on 30 statement items, can be seen in table 2 .

Table 2.the results of the calculations show that the number of answers to each item asked by the respondent. Scores Based on Respondents' Responses About Leadership Effectiveness Principal of SMK Negeri 3 Tanah Putih, Kab.Rokan Hilir, Riau

\begin{tabular}{|r|l|c|c|}
\hline Bobot & Kategori & Jumlah & \% \\
\hline 1 & Ineffective & 61 & 6,4 \\
\hline 2 & ess effective & 159 & 16,6 \\
\hline 3 & Effective & 453 & 47 \\
\hline 4 & Very effective & 287 & 30 \\
\hline
\end{tabular}

From the data above, there are nearly 30 percent said to be very effective, 47 percent effective, the remaining around 23 percent said it was less effective.

If the calculation results of this variable are extended further to determine the level of leadership effectiveness, then a comparison of the number of scoring scores (with a score of 2886) is compared to the highest ideal score $=4 \times 30$ items $\times 32$ respondents $=3840$. So the ratio is $=(2886 / 3840) \times 100 \%=75.15 \%$. This describes that the principal's effectiveness level is around $75 \%$ of ideal conditions.

\section{Discussion}

Analysis of the Effects of Leadership on the Nature and Effectiveness of Leadership.Based on the processing of research data, with Ms-Excel and SPSS tools, it is known that the correlation values of the two variables: $\mathrm{R}(\mathrm{xy})=0.489$ are categorized as quite significant. Another result, states that the correlation coefficient $[\mathrm{R}(\mathrm{xy})]$ is significant at the $1 \%$ test level. This is stated from the value of Sig $=0.005$ or $0.5 \%$. This means statistically, the correlation coefficient is reliable (sure is true) of $99.5 \%$.

Based on the results of the test, which concluded that there was a positive correlation between the variables of the study, then the influence of Leadership can be analyzed as independent variables $(\mathrm{X})$ on the Effectiveness of Leadership as a Dependent (Y) variable. For this reason, a quantitative approach is used with the regression model $\mathrm{Y}=\mathrm{a}+\mathrm{b} \mathrm{X}$.

\section{Conclusion}

Based on the SPSS analysis output, there are three (3) outputs produced, each of which states:

1. Model Summary: that the linear relationship model of the nature (X) leadership variable and leadership effectiveness (Y) of the Head of the SMK Negeri 3 Tanah PutihRokanHilir Regency, Riau has a positive correlation of $\mathrm{R}=0.489$ the degree of relationship is $\mathrm{R}$-square $=23.9$ percent.

2. Table Anova: states the test model is the linearity of the relationship between the nature of leadership (X) and the effectiveness of leadership (Y) in the equation: $\mathrm{Y}=\mathrm{a}+\mathrm{b} \mathrm{X}$ which is assumed. With Fstatistics of 9.414 and Significance Test (Sig) of 0.005 , then the regression model $\mathrm{Y}=\mathrm{a}+\mathrm{bX}$ can be accepted with a statistically correct confidence level of $99.5 \%$ /

3. Coefficient table: is a table that estimates the value of constants and coefficients of the regression model, so it can be written the regression model $\mathrm{X}$ over $\mathrm{Y}$ in the equation: $\mathrm{Y}=58.999+0.378$ XAnd from the value of the $t$ test, the two values (constants and regression coefficients) are declared significant. Because the value of Sig (a) $=0,000$ and Sig $(b)=0.005$ is the second regression variable in the form of: $\mathrm{Y}=58.999+0.378 \mathrm{X}$

Meaning: Changes or ups and downs of the weight of $\mathrm{X}$ will affect the size of $\mathrm{Y}$ by $37.8 \%$. In other words, the contribution of the influence of the leadership variable on the effectiveness of the leadership of the head of the SMK Negeri 3 Tanah PutihRokanHilir regency, Riau reached $37.8 \%$, meaning that there were still many other factors affecting the effectiveness of the headmaster's leadership of $62.2 \%$. 


\section{References}

[1] Handoko, Hani.T. (2003). Manajemen.Edisi 2.Yokyakarta: BPFE

[2] Sagala Syaiful, H (2013) Manajemen Strategi dalam Peningkatan Mutu Pendidikan, Alfabeta,CV

[3]Tony Bush (2008) Leadership andManagement Development in Education, SAGE Publications Inc.Fenwick W. English (2006) Educational Leadershipand Administration, SAGE Publications Inc.

[4] Setyabudi Indartono (2005) Leadership, Gemailmu Yogyakarta

[5] Lussier, Robert N. (2009). Management Fundamen-tals. Concepts- Applications -Skill Develop-ment. Printed in the USA.

[6] Rivai, Veithzal. \&Murni, Sylviana (2009). Education Management, AnalisisTeoridanPraktik. Jakarta :Rajawali Pers.

[7] Rivai, Veithzal. (2003). Kepemimpinan Dan Perilaku Organisasi. Jakarta: Raja Grafindo

[8] Robbins, Stephen P. \& Coulter, Mary.(2007). Manajemen.Jilid 1.Jakarta :Indeks

[9] Robbins, S.P. (1998). Perilaku Organisasi, Konsep, Kontroversi, Aplikasi. Jakarta : Prenhallindo

[10] Siagian (2001), Ciri-ciri Kepemimpinan. Bandung. Rineka Cipta.

[11] Stogdill (1994), Leadership. Jakarta: Ghalia Indo

[12] Wiludjeng (2007).Pengantar Manajemen. Yogyakarta: Graha Ilmu

[13] Yulk, Gary. 2009. Kepemimpinan Dalam Organisasi. Jakarta: Indeks, Iklan

[14] Blake, Robert, dkk. (1992), Pemimpin dan Kepemimpinan. Jakarta : Raja Grafindo Persada Journal School Principals' Authentic Leadership and Teachers' Psychological Capital: Teachers'Perspectives oleh Feng Feng-(2016) International Education Studies; Vol. 9, No. 10; 2016 ISSN 1913-9020 E-ISSN 1913-9039 Published by Canadian Center of Science and Education

[15] Journal ( 2017 - Volume 8 ) PERSPEKTIF KEPEMIMPINAN PENDIDIKAN UNTUK SEKOLAH EFEKTIF Oleh : Slamet Lestari

[16] Journal (2016 - Volume 3) Transformational Leadership: What's Your Motivation Oleh : Eileen Des Autels Wiltshire 